\title{
Skjoldryggen terminal moraine on the mid-Norwegian Shelf
}

\author{
J. A. DOWDESWELL ${ }^{1 *}$, D. OTTESEN ${ }^{2} \&$ L. RISE ${ }^{2}$ \\ ${ }^{1}$ Scott Polar Research Institute, University of Cambridge, Cambridge CB2 IER, UK \\ ${ }^{2}$ Geological Survey of Norway, Postboks 6315 Sluppen, N-7491 Trondheim, Norway
}

*Corresponding author (e-mail:jd16@,cam.ac.uk)

Terminal moraines are relatively large ridges of diamictic glacial debris produced at the outermost margins of past glaciers and ice sheets. Their identification on land is important in mapping the maximum extent of Quaternary ice sheets (Svendsen et al. 2004). In marine environments where fast-flowing ice streams reach the shelf edge during full-glacial intervals, moraine ridges are not usually present and the seafloor is characterised by parallel-to-flow streamlined sediments (Ottesen \& Dowdeswell 2009). Submarine terminal moraine ridges, by contrast, appear more typical of slower-flowing ice margins (Dahlgren et al. 2002; Dowdeswell \& Elverhøi 2002).

\section{Description}

A very large ridge, about $150 \mathrm{~km}$ long and up to approximately $200 \mathrm{~m}$ high relative to the adjacent shelf, is located on the outermost part of the mid-Norwegian continental shelf edge between about $65^{\circ}$ and $66^{\circ} \mathrm{N}$ (Fig. 1a). It is known as Skjoldryggen ('skjold' means 'shield' and 'ryggen' means 'the ridge' in Norwegian). Along most of its length, the ridge has a steeper offshore slope relative to that on its landward side. Inshore of the ridge, the water deepens from 200 to $300 \mathrm{~m}$ to between about 300 and $500 \mathrm{~m}$ in depth in the cross-shelf trough of Sklinnadjupet (Andersen 1979; Dahlgren et al. 2002a; Ottesen et al. 2005).

The morphology of the approximately $200 \mathrm{~km}$-wide shelf between Skjoldryggen and the coast of Norway is complex (Fig. 1b). There are several pronounced indentations on the inshore side of the ridge itself (Fig. 1a). The shelf contains several isolated mounds and quasi-linear ridges of glacial debris, along with hill-hole pairs (Ottesen et al. 2005). The presence of streamlined mega-scale glacial lineations (MSGLs) on the seafloor immediately inshore of the northeastern part of Skjoldryggen (Fig. 1c), and the burial of some MSGLs by subsequent glacial deposition, suggests that ice flow was complex during the Late Weichselian deglaciation (Ottesen et al. 2005).

Seismic-reflection data show that Skjoldryggen is underlain by a series of prograding wedges of Quaternary sediments (Fig. 1d), and the shelf break appears to have migrated roughly $100 \mathrm{~km}$ over this period (Dahlgren et al. 2002). The sediments above the Base-Naust horizon, which marks the beginning of Quaternary glaciation at $2.7 \mathrm{Myr}$ ago, are a total of about $1,000 \mathrm{~m}$ in thickness beneath the ridge. Debris interpreted to be from Weichselian, Saalian and Elsterian ice advances across the shelf is about $500 \mathrm{~m}$ thick in total (Fig. 1d; Rise et al. 2006). The acoustic character of the sediments making up Skjoldryggen is largely transparent to chaotic, which is typical of diamictic glacial debris.

\section{Interpretation}

Skjoldryggen is interpreted to be a terminal moraine, marking the furthest advance of the full-glacial Fennocandian ice sheet across the wide mid-Norwegian shelf to the shelf edge during the latest, Weichselian glaciation. The ridge (Fig. 1a) has been described by Andersen (1979) as 'one of the most impressive end moraines in the world.' The growth of terminal moraines is thought to involve the mobilisation and push of sediments at ice-sheet margins, enabling the build-up of ridges of debris at their marine termini. There must be vertical accommodation space to build such a ridge. This implies that the ice-sheet terminus at the time of ridge formation must have been more or less vertical, rather than having a floating tongue beyond the grounding-zone that would have restricted vertical growth. The presence of hill-hole pairs inshore of the terminal moraine also suggests that basal thermal conditions were variable, with parts of the bed being frozen at least for a time in order to entrain and remove the sediment from 'holes' and then deposit is as adjacent 'hills' (Ottesen et al. 2005). This process may have contributed to the building of some parts of the terminal moraine ridge.

Sets of MSGLs adjacent to the northeastern part of the ridge, orientated in several directions (Fig. 1c), imply that a number of ice lobes were active during deglaciation. This may explain several of the indentations on the ice-proximal side of the terminal moraine ridge (Fig. 1a) and elements of the complex topography of the adjacent shelf (Fig. 1b). However, the overall geometry of the shelf and the concave-inward shape of the terminal moraine, imply that ice flow was largely divergent. Such flow divergence requires a reduction in ice velocity. This is compatible with the idea that terminal moraines are produced mainly by relatively slow-flowing ice, compared to the streamlined linear features produced by fast ice-stream flow (Ottesen \& Dowdeswell 2009).

\section{References}

ANDERSEN, B. G. 1979. The deglaciation of Norway 15,000-10,000 B.P. Boreas, 8, 79-87.

DAHLGREN, K. I. T., VORREN, T. O. \& LABERG, J. S. 2002. The role of grounding-line sediment supply in ice-sheet advances and growth on continental shelves: an example from the mid-Norwegian sector of the Fennoscandian ice sheet during the Saalian and Weichselian. Quaternary International, 95-96, 25-33.

DOWDESWELL, J. A. \& ELVERHØI, A. 2002. The timing of initiation of fast-flowing ice streams during a glacial cycle inferred from glacimarine sedimentation. Marine Geology, 188, 3-14.

OTTESEN, D. \& DOWDESWELL, J. A. 2009. An inter-ice stream glaciated margin: submarine landforms and a geomorphic model based on marine-geophysical data from Svalbard. Geological Society of America Bulletin 121, 1647-1665.

OTTESEN, D., DOWDESWELL, J. A. \& RISE, L. 2005. Submarine landforms and the reconstruction of fast-flowing ice streams within a large Quaternary ice sheet: the 2500-km-long Norwegian-Svalbard margin $\left(57^{\circ}-80^{\circ} \mathrm{N}\right)$. Geological Society of America Bulletin 117, 1033-1050.

RISE, L., OTTESEN, D., LONGVA, O., SOLHEIM, A., ANDERSEN, E. S. \& AYERS, S. 2006. The Sklinnadjupet slide and its relation to the Elsterian glaciation on the mid-Norwegian margin. Marine and Petroleum Geology, 23, 569-583. 
SVENDSEN, J. I., ALEXANDERSON, H. et al. 2004. Late Quaternary ice sheet history of northern Eurasia. Quaternary Science Reviews, 23, 1229-1271.

Fig. 1. (a) Bathymetric map of Skjoldryggen terminal moraine on the mid-Norwegian shelf, located in (b). (b) Regional bathymetry of Skyoldryggen and the adjacent mid-Norwegian shelf. Data in (a) and (b) from single-beam echo sounding with a mean line-spacing of $500 \mathrm{~m}$. (c) Detailed image of the northeasternmost part of the ridge and adjacent shelf, located in (b). The image show the seabed reflection with several sets of glacial lineations, partially overlain by a large glacial sediment lobe. Data from a 3D seismic cube gridded with a cell-size of $25 \mathrm{~m}$. (d) Reflection-seismic profile across Skjoldryggen and the adjacent shelf and continental slope, located in (b). VE x 30. (e) Location of study area (red box; map from IBCAO v. 3). 


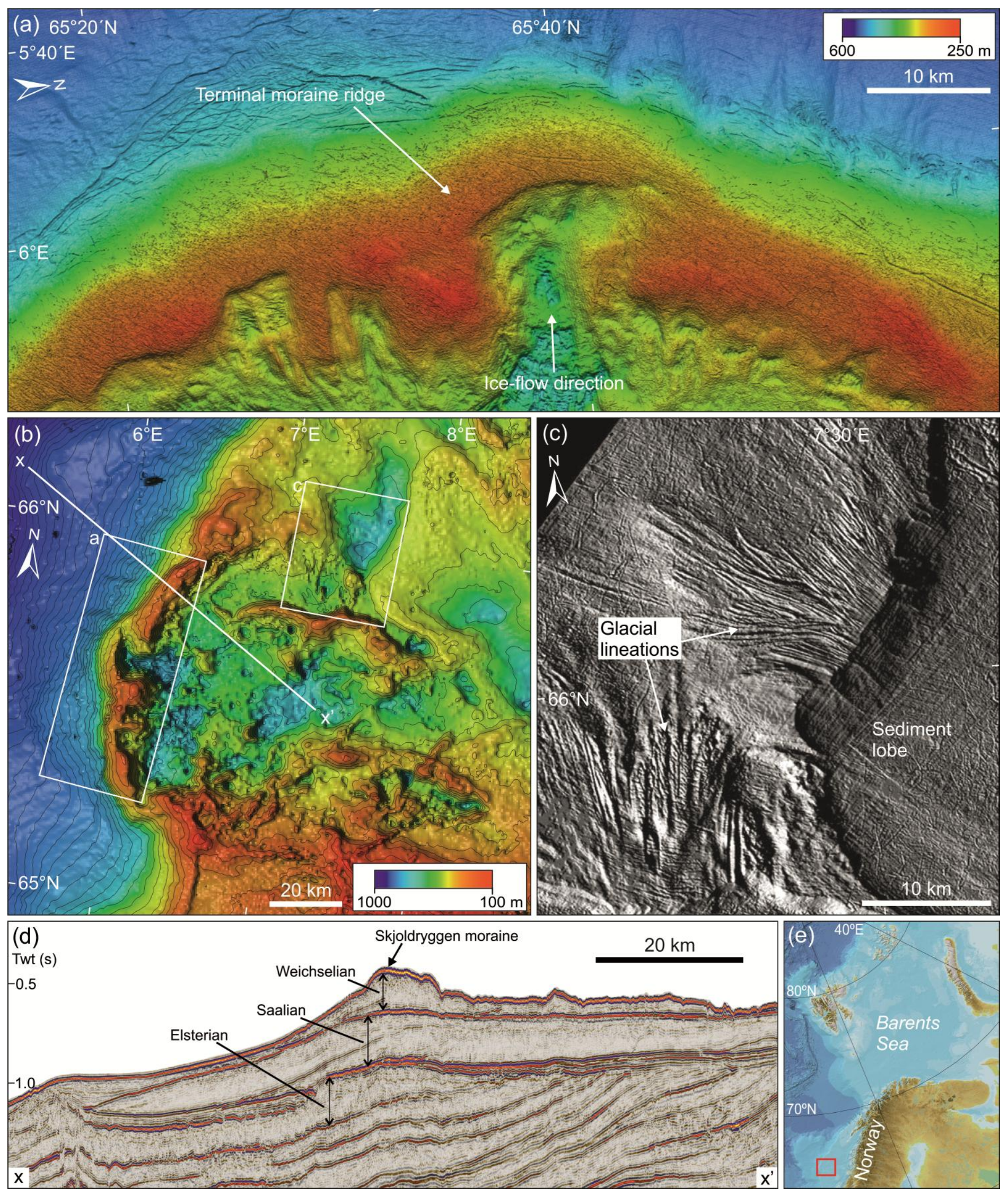

